Article title: A Distributed Perspective on the Community-of-Inquiry Framework for Distance Education Authors: Piera Biccard[1]

Affiliations: University of South Africa[1]

Orcid ids: 0000-0002-2663-8454[1]

Contact e-mail: biccap@unisa.ac.za

License information: This work has been published open access under Creative Commons Attribution License http://creativecommons.org/licenses/by/4.0/, which permits unrestricted use, distribution, and reproduction in any medium, provided the original work is properly cited. Conditions, terms of use and publishing policy can be found at https://www.scienceopen.com/.

Preprint statement: This article is a preprint and has not been peer-reviewed, under consideration and submitted to UnisaRxiv for open peer review.

DOI: 10.25159/UnisaRxiv/000009.v1

Preprint first posted online: 06 July 2021

Keywords: community of inquiry, distributed approach, distance education 


\title{
A Distributed Perspective on the Community-of- Inquiry Framework for Distance Education
}

\author{
Piera Biccard \\ https://orcid.org/0000-0002-2663-8454 \\ Department of Curriculum and Instructional Studies, University of South Africa \\ biccap@unisa.ac.za
}

\begin{abstract}
This conceptual paper sets out the community-of-inquiry framework from a distributed perspective. It proposes that considering teaching presence, social presence and cognitive presence from a distributed perspective allows the broadening of the presences to consider the way in which participants, content and tools maintain and advance these presences. Distance education is problematic since the separation of instructor and student necessitates a change of pedagogy. The paper argues that by distributing the typical silos of "teaching" and "learning", more flexible opportunities are enabled. The distribution of the three presences across participants, content and tools is proposed as one way of mitigating distances in distance education. It is recommended that the proposed model be subject to empirical research to ascertain the usefulness of the model in practice.
\end{abstract}

Keywords: community of inquiry; distributed approach, distance education

\section{Introduction}

From the early stages of the Covid pandemic in 2020, many educational institutions moved into the online space to facilitate social distancing in education and so a unique form of "distance education" took shape. Distance learning can be traced back to the advent of the postal system in which communication between instructors and learners was paper-based and the term correspondence education was used. As communication technologies changed over time, so did the mode of distance education, with broadcast technologies such as radio and television harnessed as communication mechanisms for distance learning. More recently, computers, the internet and Web2.0 technologies have allowed a proliferation of various online options to become part of distance education. As a result, many forms of distance education have become possible and numerous terms have been developed to describe various distance education modes such as elearning, web-based learning, online learning, and technology mediated learning or virtual learning (Moore, Dickson-Deane, and Gaylen 2011, 129). For the purpose of this paper, distance learning is understood as formal learning that takes place where students are separated (geographically) from each other and from the instructor and only "meet" via some technology. This mode of learning is challenging because when students feel isolated or remote they tend to disengage or even drop out (Russo and Benson 2005, 54). 
Likewise, where teacher interaction with students is high, online learning outcomes improve (Shea and Bidjerano 2010, 1721).

The "distance" in distance education has been theorised from its early days. Peters $(2010,11)$ described distance education as the most industrialised form of learning. Industrialisation encompasses ideas of assembly lines, mechanisation and time-space separation (Peters 2010, 14), all terms that are inherent in distance learning. Moore's (1997) theory of transactional distance sets out and analyses relationships between course structure, dialogue and student autonomy. Holmberg (2004) asked for an empathetic tone or empathetic approach to be embedded in the instructional materials to mediate the distances in distance education. In a change from the word "distance" to "presence", Garrison, Anderson and Archer $(2000,88)$ set out three fundamental presences necessary for collaborative knowledge construction in student-centred learning experiences known as the community-of-inquiry (CoI) framework. With the migration of many educational spaces into an online-distance form, a renewed interest in the CoI's theoretical ideas in the pandemic-driven educational spaces may be relevant.

The CoI framework sets out three interlinking and interdependent "presences" in online learning spaces. They present the concepts of teaching presence, social presence and cognitive presence in a Venn diagram (see Figure 1) with overlapping spaces such as setting content, supporting discourse and setting climate to characterise these overlapping areas. Teaching presence encompasses pedagogical action from the instructor such as course design and organisation, catalyses discourses, and provides instruction. Social presence is set in motion by the instructor or included in discussion tools embedded as part of the design of the course. These "instructional conversations [...] are likely to lead to epistemic engagement" (Shea and Bidjerano 2010, 1722). Cognitive presence refers to the way in which learners construct meaning, engage in deep learning and are able to think critically about the content (Garrison, Anderson, and Archer 2000, 98).

The labels of the intersecting areas suggest that instructors (through their teaching presence) provide cognitive presence through the content that is selected for the course, while they use both their teaching presence and social presence to create an engaging climate in the course. The cognitive presence of the course (knowledge, ideas, and concepts) supports the discourse through the social presence (of instructor and students) in the course and vice versa. 


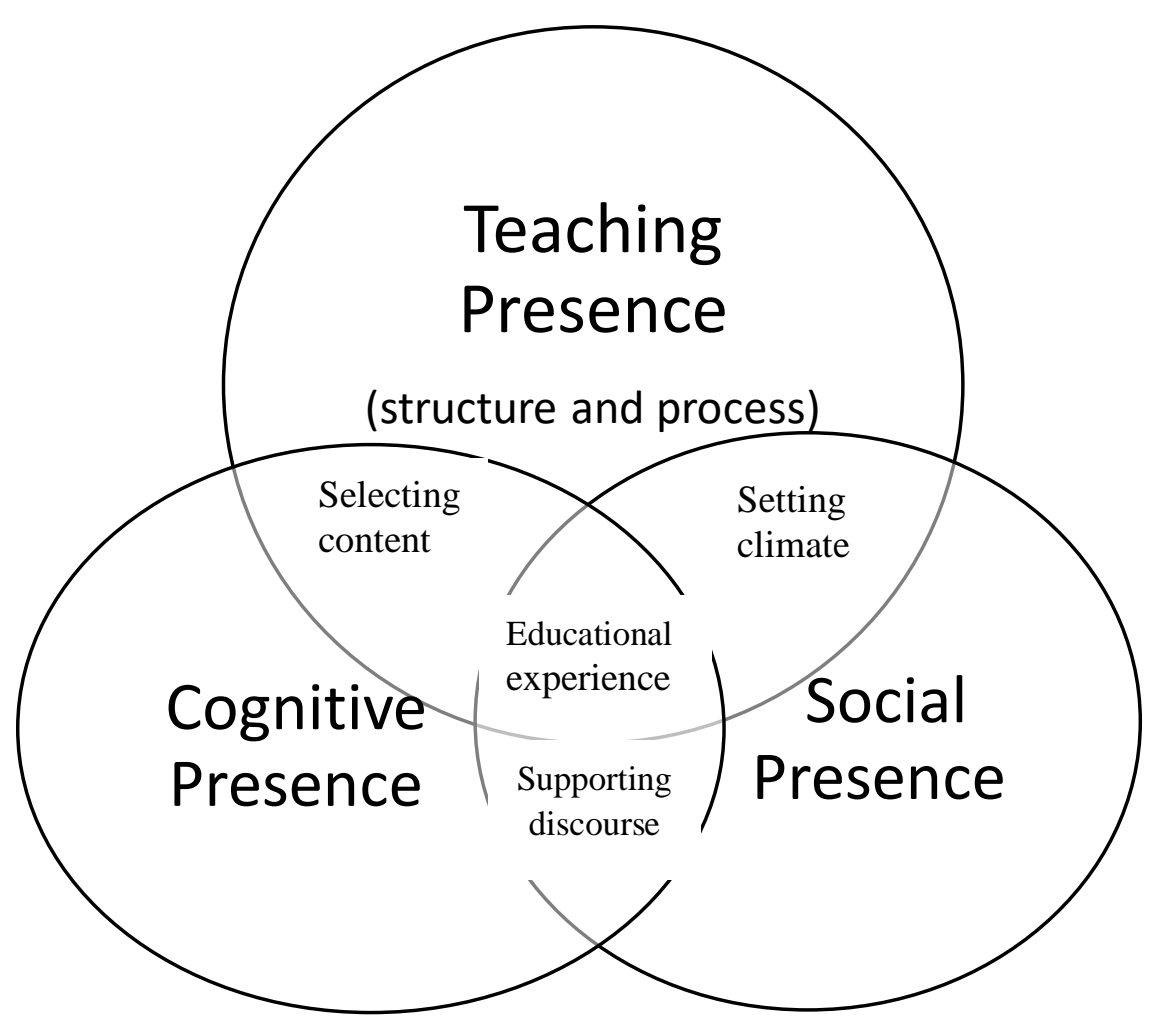

Figure 1: Community of inquiry (Garrison, Anderson, and Archer 2000, 88)

Although the CoI model represents a "coherent conceptual structure" (Shea and Bidjerano 2010, 1722), these authors cite empirical research in which many instances of learner discourse could not be accommodated in the model. These authors also found evidence that learners were engaged in discussion regarding managing time, understanding instructions or setting up group tasks and goals. Learners in online learning environments are "metacognitively, motivationally, and behaviourally active participants in the learning process" (Shea and Bidjerano 2010, 1723). For this reason, they found that although CoI represents a concise descriptive model, it is limited in expressing the roles of online learners.

Similarly, other authors have called for the revision of the CoI model to include a learning presence (Shea and Bidjerano 2010; Shea et al. 2013; Gregory and BannisterTyrrell 2017; Hayes, Smith, and Shea 2015; Ma et al. 2017; Pool, Reitsma, and Van den Berg 2017). In other studies (cf. Cleveland-Innes and Campbell 2012; Lam 2015; Russo and Benson 2005) affective, emotional and autonomy presences have been proposed as additions to complement or advance the CoI framework; however, the call for learning or learner presence to be added seems to be most persistent. 
In exploring a different perspective on teaching presence in the CoI framework, the work of Coll, Engel and Bustos (2009) and Paz and Pereira (2015) is relevant. Instead of trying to add another presence to the framework, these authors consider distributed teaching as a way of understanding teaching presence. Coll, Engel and Bustos $(2009,523)$ propose that a distributed teaching presence "refers to the fact that educational influence can be exercised both by the teacher and the other participants, who can contribute to the communicative, social and cognitive processes involved in learning through their actions". These authors also remind us that the term chosen by Garrison, Anderson and Archer $(2000,101)$ is teaching presence, and not teacher presence. This implies that students can move into the teaching space, in what Paz and Pereira $(2015,3)$ termed the dissociation of participants with their function. This fluidity in teaching may also be linked to communities of practice (Wenger 1998) and apprenticeship learning. In the same vein, it is possible (desirable) in distance online learning that course materials such as readings or videos can also provide teaching presence.

The argument of this paper is that each of the three elements (and the overlapping areas) of the CoI should be distributed across participants, content and tools (for example, physical apparatus, digital software or language) of the learning space or educational experience. Furthermore, the challenges scholars have had with the CoI (that prompted a debate about whether the model was complete or what other presences needed to be added to the model) can be accommodated by understanding the model from a distributed perspective. Lea and Nicoll $(2002,33)$ broadly defined distributed learning as focussing on shifting paradigms in the ways teaching and learning can be distributed across space and time. Although a distributed approach to teaching presence is proposed in the literature (for example, Coll, Engel, and Bustos 2009; Swan, Chen, and BokmierSommers 2020), it can be argued that the distributed perspective of all three CoI presences should be an intentional design aspect of distance online courses. Victor and Hart $(2016,1503)$ set out a distributed learning model for blended learning consisting of technology, learning experiences and people, but their model only focuses on social presence. This paper seeks to harmonise all three CoI presences by proposing a distributed approach to all three.

This paper aims to add more detail to the underlying structure (Hayes, Smith, and Shea 2015,16 ) and further the qualitative perspective of the CoI (Pool, Reitsma, and Van den Berg 2017, 153). Therefore, the following research question is relevant:

- How can the CoI be conceptualised from a distributed perspective?

\section{Conceptual Methodology}

Conceptual articles are an important process in theory building in a field. A "welldesigned conceptual paper must explicitly justify and explicate decisions about key elements of the study" (Jaakkola 2020,19). In conceptual articles, the arguments are 
developed from previously developed concepts and theories (Hirschheim 2008, 432) and new relationships among elements are proposed (Jaakkola 2020, 19). The links between concepts are explained theoretically rather than empirically. Although conceptual papers are based on literature, they are different from literature reviews in that they propose a "what's new" element (Gilson and Goldberg 2015, 128). Jaakkola $(2020,18)$ sets out four types of conceptual article (theory synthesis, theory adaptation, typology and model); this paper follows the model approach.

In the model approach to conceptual articles, this study's starting point is a domain theory (for example, the $\mathrm{CoI}$ framework). The aim is to explain relationships (or suggest novel connections) between the key elements of the theory by using literature. In this paper, literature related to key concepts (teaching presence, cognitive presence and social presence) is targeted to explore the novel idea of distribution or a distributed perspective. This delimitation of the literature search exposes why certain literature is referred to, in what Jaakkola $(2020,24)$ refers to as a "literature pool". Once the connections are explored and explained, conceptual articles often conclude with a diagram (Fulmer 2012, 327; Jaakkola 2020, 24), which in this study is Table 1.

\section{Key Concepts}

In trying to understand the CoI from a distributed perspective, the three distribution points proposed in this paper are: participants, content and tools. Participants and content have always been part of the educational landscape, but with the growing presence of technology in learning, it can provide both content and new tools for learning. Siemens $(2004,6)$ argued that "Technology is altering (rewiring) our brains. The tools we use define and shape our thinking". In addition, if we acknowledge that learning is distributed across people and tools, then this changes what we do with technology (Pea 1993, 58).

The literature review will therefore be aimed at the way in which the three CoI presences are distributed across participants, content and tools in the educational experience.

\section{Teaching Presence as Distributed Teaching}

Distance education includes a continuum of pedagogical approaches from traditional online instruction that is fully teacher-prepared and directed to facilitated online collaboration that requires active peer-to-peer and peer-to-instructor interaction. A growing focus on the nature of teaching in online or distance spaces is evident (Cutri and Mena 2020, 362; McGee, Windes, and Torres 2017, 332).

In some research (for example, Richardson and Swan 2003, 69), the distributed approach to teaching can be traced through the changing vocabulary evident when referring to instructors and students. Terms such as "facilitators of learning" when referring to teachers and "active learners" may imply a distributed approach to teaching. 
For Paz and Pereira $(2015,3)$, the distribution of teaching presence can be built into the teaching design or occur as a natural process during the course. Even though Fiock $(2020,139)$ set out the way in which online courses can be designed effectively by integrating seven principles of good practice in the CoI framework, the instructional activities suggested by Fiock are largely allocated to the teacher and not distributed. Garrison $(2015,87)$ emphasises the "transactional nature of thinking and learning collaboratively". Transactions assume that responsibilities are distributed across the educational space.

The call to extend the CoI framework with learning presence may stem from insufficiently interrogating the way in which technologically mediated teaching can be distributed. Some researchers (cf. Banas and Wartalski 2019, 8) see the online learning space as a community of practice, where knowledge is created, expanded, and exchanged (Wenger, McDermott, and Snyder 2002, 42). Students specifically need to share ideas, listen to other perspectives and co-construct knowledge (Dabbagh, Marra, and Howland 2019, 134) for robust learning to take place.

Anderson $(2004,274)$ sets out that "teaching presence is delegated to or assumed by students as they contribute their own skills and knowledge to the developing learning community" which suggests a need to elevate students from consumers to producers of knowledge. Furthermore, it suggests equity in the educational space. Delegating the function of teaching to students encompasses a paradigm shift from behaviourist teaching principles to connectivist teaching principles. In a connectivist paradigm, "learning and knowledge rests in diverse opinions" and "may reside in non-human appliances" (Siemens 2004, 5). However, knowing each tool's affordances (Pea 1993, 51) necessitates that the instructional designer has good technological pedagogical content knowledge (Mishra and Koehler 2006, 1017). The distribution of teaching across participants, content and tools allows for a wider integration of the elements of the educational space.

Perhaps more important, is the idea from the field of distributed cognition that the analysis of the interactions between the different components is imperative (Perry 2003, 195; Rogers 1997, 2) to fully consider teaching presence as distributed teaching.

\section{Cognitive Presence as Distributed Cognition}

If we view the mind as "as a dynamic system of interactions inclusive of human agents, technologies and other material things" (Shutkin 2019,481), then a distributed cognition perspective on cognitive presence allows us to draw in numerous definitions and role players in cognitive presence, without the need to extend the CoI framework by including other presences. Selecting content as one of the subcomponents of cognitive presence also assumes structuring the content and creating a learning trajectory in terms of sequencing. It may be possible to distribute the selection of content to the students. Within a topic, the student may be able to select the appropriate content to meet the outcomes, or to make choices from a variety of readings and texts. 
In the case of discussion forums being used to facilitate cognitive presence, Darabi et al. $(2011,224)$ conclude that forums in which students have to take a stance in an authentic scenario, engender cognitive presence. In this case, the scenario is distributed across participants who have different solutions and reasoning; it is through being exposed to different perspectives that students develop increased understanding (Darabi et al. 2011, 224). One of the main motivations for moving computer systems to a distributed design is resource sharing (Wu 2020,2). In the case of online learning, resource finding (for example, finding content, approaching specialists in the field or finding useful apps or technologies) underscores a distributed approach. Resource finding further promotes a distributed approach to social presence (inviting specialists to the discussion) and cognitive presence (sharing relevant course material).

\section{Social Presence as Distributed Social Interaction}

The social nature of education has been proposed for a long time (Dewey 1910; Vygotsky 1978). Even if students are participating in fully online courses, social exchanges about the outcomes, content and assignments of the course are a necessary part of learning. Moore $(1989,2)$ outlined three important interactions or distributions of interactions for distance education, namely, student-content interaction, studentinstructor interaction, and student-student interaction. Anderson $(2003,1)$ continued to argue for these three types of interaction, but looked more critically at "getting the mix right". Interactions as the basis of social presence are therefore distributed across participants, content and tools. Definitions of social presence that only focus on the interaction between students may lack important qualities of social presence emanating from the other interactions. Students may interact with each other socially (for example, greetings and inquiring about sport results, stress levels). They may interact with each other on an academic basis, for example discussing the prescribed material, and they may interact with the instructor, which provides a feedback loop to teaching presence.

Sailsman $(2020,48)$ posited that "social presence requires positive group cohesion, fluid communication, and consistent engagement"; the distributed nature is implicit in this clarification. Group cohesion is a responsibility that should be devolved to both students and instructors. Fluid communication can be distributed across participants and the tools used for communicating, whereas consistent engagement comes about largely from teaching presence that engages and extends student thinking with the prescribed resources. For Zhao, Sullivan and Mellenius $(2014,816)$, participation is the first step that may lead to interaction and finally to collaboration. The instructor initiates the participatory social space and supports and guides the interaction until students "takeup" this function and social presence is distributed to them.

Distributed social presence also acknowledges that the participants in the course are seen as resources. Providing spaces in which the participants can draw on each other's knowledge of content or tools allows for a distributed approach. This may be optimally achieved if course design includes collaborative problem-solving or making collaborative artefacts part of the course outcomes. 


\section{Discussion}

The discussion takes the form of a framework that sets out the way in which the CoI presences can be distributed across participants, content and tools. Although Table 1 sets out some ideas for the distribution it is not exhaustive and needs to be tested empirically.

Table 1: A distributed approach to distance education course design

\begin{tabular}{|c|c|c|c|}
\hline & Participants & Content & Tools \\
\hline $\begin{array}{l}\text { Teaching } \\
\text { presence }\end{array}$ & $\begin{array}{l}\text { Analyse course } \\
\text { participants. Refer to } \\
\text { demographical } \\
\text { background information } \\
\text { regarding the participants. } \\
\text { Reflect on which aspects } \\
\text { of "teaching" can be } \\
\text { devolved to them. } \\
\text { Contemplate special } \\
\text { guests or outsiders who } \\
\text { can join the course at } \\
\text { times. }\end{array}$ & $\begin{array}{l}\text { Find or create content } \\
\text { that can provide a } \\
\text { teaching presence } \\
\text { (reading matter, videos, } \\
\text { podcasts, etc.) } \\
\text { Consider the content } \\
\text { that students can } \\
\text { find/design/produce for } \\
\text { the course. }\end{array}$ & $\begin{array}{l}\text { Harness tools that can } \\
\text { provide teaching presence } \\
\text { (editing software, word } \\
\text { analytics, etc.) } \\
\text { Consider the use of a } \\
\text { course app that can send } \\
\text { reminders, notifications, } \\
\text { etc. }\end{array}$ \\
\hline $\begin{array}{l}\text { Cognitive } \\
\text { presence }\end{array}$ & $\begin{array}{l}\text { Interaction of participants } \\
\text { with content, ideas, and } \\
\text { concepts. Cognitive } \\
\text { equity among course } \\
\text { participants must be } \\
\text { encouraged. } \\
\text { Participants as sources of } \\
\text { cognitive information } \\
\text { should also be stimulated. }\end{array}$ & $\begin{array}{l}\text { The content selected or } \\
\text { shared during the course } \\
\text { sets the tone for the } \\
\text { cognitive presence of } \\
\text { the course. Resource } \\
\text { sharing should be } \\
\text { encouraged. }\end{array}$ & $\begin{array}{l}\text { The technological (and } \\
\text { other) tools used } \\
\text { contribute to the cognitive } \\
\text { presence, e.g. the use of } \\
\text { referencing software or } \\
\text { mind maps/concept map } \\
\text { software. }\end{array}$ \\
\hline Social presence & $\begin{array}{l}\text { Distribution of } \\
\text { communication and } \\
\text { interaction must be a } \\
\text { design feature. } \\
\text { Higher order engagement } \\
\text { (e.g. creating joint } \\
\text { artefacts) and } \\
\text { collaboration must be } \\
\text { factored into the course } \\
\text { design. }\end{array}$ & $\begin{array}{l}\text { Provision of interesting } \\
\text { or conflicting or } \\
\text { authentic content may } \\
\text { allow an increased } \\
\text { social presence. } \\
\text { Students may be } \\
\text { motivated by the } \\
\text { content to become } \\
\text { socially present in the } \\
\text { course. } \\
\text { Designing a course in } \\
\text { which students need to } \\
\text { share their own } \\
\text { resources and content } \\
\text { may increase social } \\
\text { presence in the course. }\end{array}$ & $\begin{array}{l}\text { A decision needs to be } \\
\text { made in terms of the type } \\
\text { of tools used for } \\
\text { communication and } \\
\text { interaction (e.g. emails, } \\
\text { discussion forums, mobile } \\
\text { chat apps.) that can } \\
\text { contribute to the social } \\
\text { presence of the course. }\end{array}$ \\
\hline
\end{tabular}

What may be apparent from Table 1 is that distributing the teaching, cognitive and social presence across participants, content and tools is a necessary condition for "openness" in open distance learning. Zawacki-Richter et al. $(2020,324)$ posited that 
the theoretical notion of openness in open distance e-learning goes beyond issues of access to education but also acknowledges that the roles of teachers and learners change considerably. This may include a distributed perspective regarding these roles. By distributing the three presences of the CoI, openness may be promoted in a course or programme.

\section{Conclusion}

For Moore $(1989,4)$, a weakness of distance education is to employ only one type of medium or approach. With a distributed perspective of distance education and online learning, more choices and design factors are apparent and therefore more flexibility can be created in courses. A distributed approach to the CoI may help us to make adaptions to new trends in online learning. By considering each presence in the $\mathrm{CoI}$ and the way in which the presence can be distributed across participants, content and tools, richer understanding of the three presences is possible. One of the benefits of a distributed approach is that a course can be more sensitive and flexible to changing technology and user needs (Wu 2020, 2).

Presences such as teaching presence and cognitive presence that are traditionally the instructor's responsibility can be reframed by distributing them across participants and tools. The existing CoI framework already proposes some distribution between teaching presence, social presence and cognitive presence by labelling the overlapping Venn diagram sections as selecting content, setting climate and supporting discourse. A distributed perspective on the $\mathrm{CoI}$ framework also allows more possibility for interaction between participants, content and tools within these intersecting areas.

For Moore $(2019,33)$, the distances inherent in distance education bring about new "patterns of behaviour". These new patterns of behaviour may require a distributed approach as suggested in this paper. A distributed approach could mediate the transactional distance in distance learning since it can be seen as an enabler of more student involvement and an enabler of openness. However, it may be argued that distribution brings increased uncertainty in course design. Depending on the course content and outcomes, not all aspects of a course can be distributed. Carefully considered distribution of teaching, cognitive and social presence among participants, content and tools requires instructors who have astute technological pedagogical content knowledge (Mishra and Koehler 2006, 1017) and who take part in continual professional development in the field of distance education.

Knowing what and when to distribute in course design is an important consideration, but more challenging and significant is knowing how and why to distribute the CoI presences. This paper hopes to spotlight the potential discussions that can emanate from a distributed paradigm. 


\section{References}

Anderson, Terry. 2003. "Getting the Mix Right Again: An Updated and Theoretical Rationale for Interaction." International Review of Research in Open and Distributed Learning 4 (2): 1-14. https://doi.org/10.19173/irrodl.v4i2.149.

Anderson, Terry. 2004. "Teaching in an Online Context." In The Theory and Practice of Online Learning, edited by Terry Anderson and Fathi Elloumi, 271-94. Athabasca: Athabasca University Press.

Banas, Jennifer, R., and Russell D. Wartalski. 2019. "Developing a Community of Learners." Library Technology Reports 55 (4): 8-13.

Cleveland-Innes, Marti, and Prisca Campbell. 2012. "Emotional Presence, Learning, and the Online Learning Environment". International Review of Research in Open and Distributed Learning 13 (4): 269-92. https://doi.org/10.19173/irrodl.v13i4.1234.

Coll, César, Anna Engel, and Alfonso Bustos. 2009. "Distributed Teaching Presence and Participants' Activity Profiles: A Theoretical Approach to the Structural Analysis of Asynchronous Learning Networks.” European Journal of Education 44: 521-38. https://doi.org/10.1111/j.1465-3435.2009.01406.x.

Cutri, Ramona M., and Juanjo Mena. 2020. “A Critical Reconceptualization of Faculty Readiness for Online Teaching." Distance Education 41 (3): 361-80. https://doi.org/10.1080/01587919.2020.1763167.

Dabbagh, Nada, Rose Marra, and Jane Howland. 2019. Meaningful Online Learning: Integrating Strategies, Activities, and Learning Technologies for Effective Designs. New York: Routledge. https://doi.org/10.4324/9781315528458.

Darabi, Aubteen, Meagan C. Arrastia, David W. Nelson, Tom Cornille, and Xinya Liang. 2011. "Cognitive Presence in Asynchronous Online Learning: A Comparison of Four Discussion Strategies.” Journal of Computer Assisted Learning 27 (3): 216-27.

Dewey, John. 1910. How We Think. Boston: D. C. Heath.

Fiock, Holly. 2020. "Designing a Community of Inquiry in Online Courses.” International Review of Research in Open and Distributed Learning 21 (1): 135-53. https://doi.org/10.19173/irrodl.v20i5.3985.

Fulmer, Ingrid S. 2012. "Editor's Comments: The Craft of Writing Theory Articles - Variety and Similarity in AMR." Academy of Management Review 37: 327-31. https://doi.org/10.5465/amr.2012.0026.

Garrison, D. Randy. 2015. Thinking Collaboratively: Learning in a Community of Inquiry. New York: Routledge. 
Garrison, D. Randy, Terry Anderson, and Walter Archer. 2000. "Critical Inquiry in a TextBased Environment: Computer Conferencing in Higher Education." Internet and Higher Education 2 (2-3): 87-105. https://doi.org/10.1016/S1096-7516(00)00016-6.

Gilson, Lucy L., and Caren B. Goldberg. 2015. "Editors' Comment: So, What is a Conceptual Paper?" Group and Organization Management 40 (2): 127-30. https://doi.org/10.1177/1059601115576425.

Gregory, Sue, and Michelle Bannister-Tyrrell. 2017. "Digital Learner Presence and Online Teaching Tools: Higher Cognitive Requirements of Online Learners for Effective Learning." Research and Practice in Technology Enhanced Learning 12 (18): 1-17. https://doi.org/10.1186/s41039-017-0059-3.

Hayes, Suzanne, Sedef Smith, and Peter Shea. 2015. "Expanding Learning Presence to Account for the Direction of Regulative Intent: Self-, Co- and Shared Regulation in Online Learning." Online Learning 19 (3): 15-33. https://doi.org/10.24059/olj.v19i3.530.

Hirschheim, Rudy. 2008. "Some Guidelines for the Critical Reviewing of Conceptual Papers." Journal of the Association for Information Systems 9 (8). https://doi.org/10.17705/1jais.00167.

Holmberg, Borje. 2004. The Empathy Approach to Distance Education.” Lecture video, 49:02. http://youtu.be/mXRMKkHe9yE.

Jaakkola, Elina. 2020. “Designing Conceptual Articles: Four Approaches.” AMS Review 10. https://doi.org/10.1007/s13162-020-00161-0.

Lam, Chris. 2015. "The Role of Communication and Cohesion in Reducing Social Loafing in Group Projects.” Business and Professional Communication Quarterly 78 (4): 454-75. https://doi.org/10.1177/2329490615596417.

Lea, Mary R., and Kathy Nicoll, eds. 2002. Distributed Learning: Social and Cultural Approaches to Practice. New York: Routledge.

Ma, Zhiqiang, Jing Wang, Qiyun Wang, Lili Kong, Yajie Wu, and Hao Yang. 2017. "Verifying Causal Relationships among the Presences of the Community of Inquiry Framework in the Chinese Context." International Review of Research in Open and Distance Learning 18 (6): 213-30. https://doi.org/10.19173/irrodl.v18i6.3197.

McGee, Patricia, Deborah Windes, and Maria Torres. 2017. "Experienced Online Instructors: Beliefs and Preferred Supports regarding Online Teaching." Journal of Computing in Higher Education 29: 1-22. https://doi.org/10.1007/s12528-017-9140-6.

Mishra, Punya, and Matthew J. Koehler. 2006. "Technological Pedagogical Content Knowledge: A Framework for Teacher Knowledge." Teachers College Record 108 (6): 1017-54. https://doi.org/10.1111/j.1467-9620.2006.00684.x. 
Moore, Joi L., Camille Dickson-Deane, and Krista Gaylen. 2011. "E-Learning, Online learning, and Distance Learning Environments: Are they the Same?" Internet and Higher Education 14 (2): 129-35. https://doi.org/10.1016/j.iheduc.2010.10.001.

Moore, Michael. 1989. “Three Types of Interaction.” American Journal of Distance Education 3 (2): 1-7. https://doi.org/10.1080/08923648909526659.

Moore, Michael. 1997. "Theory of Transactional Distance." In Theoretical Principles of Distance Education, edited by D. Keegan, 22-38. London: Routledge.

Moore, Michael. 2019. “The theory of Transactional Distance.” In Handbook of Distance Education, edited by M. Moore and W. Diehl, 32-46. New York: Routledge. https://doi.org/10.4324/9781315296135-4.

Paz, Joao, and Alda Pereira. 2015. "Regulation of Learning as Distributed Teaching Presence in the Community of Inquiry Framework." In The Proceedings of Technology, Colleges, and Community Online Conference 2015: The Future is Now. Honolulu.

Pea, Roy D. 1993. "Practices of Distributed Intelligence and Designs for Education.” In Distributed Cognitions Psychological and Educational Considerations, edited by Gavriel Solomon, 47-87. Cambridge: Cambridge University Press.

Perry, Mark. 2003. "Distributed Cognition.” In HCI Models, Theories and Frameworks: Towards an Interdisciplinary Science, edited by John M. Carroll, 193-223. New York: Morgan Kaufmann.

Peters, Otto. 2010. “The Theory of the 'Most Industrialized Education'." In Distance Education in Transition: Developments and Issues, edited by O. Peters, 11-32. 5th ed. Oldenburg: BIS-Verlag der Carl von Ossietzky Universität Oldenburg.

Pool, Jessica, Gerda Reitsma, and Dirk van den Berg. 2017. "Revised Community of Inquiry Framework: Examining Learning Presence in a Blended Mode of Delivery." Online Learning 21 (3): 153-65. https://doi.org/10.24059/olj.v21i3.866.

Richardson, Jennifer C., and Karen Swan. 2003. “An Examination of Social Presence in Online Courses in Relation to Student's Perceived Learning and Satisfaction." Journal of Asynchronous Learning 7 (1): 68-88. https://doi.org/10.24059/olj.v7i1.1864.

Rogers, Yvonne. 1997. “A Brief Introduction to Distributed Cognition.” Accessed 15 March 2020. http://www.id-book.com/downloads/chapter\%208\%20dcog-briefintro.pdf.

Russo, Tracey, and Spencer Benson. 2005. "Learning with Invisible Others: Perceptions of Online Presence and their Relationship to Cognitive and Affective Learning." Educational Technology and Society 8 (1): 54-62.

Sailsman, Soique. 2020. "ESL Students Learning Online: A Review of Literature." Quarterly Review of Distance Education 21 (1): 45-51. 
Shea, Peter, and Temi Bidjerano. 2010. "Learning Presence: Towards a Theory of SelfEfficacy, Self-Regulation, and the Development of a Communities of Inquiry in Online and Blended Learning Environments." Computers and Education 55 (4): 1721-31. https://doi.org/10.1016/j.compedu.2010.07.017.

Shea, Peter, Suzanne Hayes, Sedef Uzuner Smith, Jason Vickers, Temi Bidjerano, Mary Gozza-Cohenm, Jian Shou-Bang, Alexandra M. Pickett, Jane Wilde, and ChiHua Tseng. 2013. "Online Learner Self-Regulation: Learning Presence Viewed Through Quantitative Content and Social Network Analysis." International Review or Research Open Distance Learning 14 (3): 427-61. https://doi.org/10.19173/irrodl.v14i3.1466.

Shutkin, David. 2019. "Representationalism and Power: The Individual Subject and Distributed Cognition in the Field of Educational Technology." Studies in Philosophy and Education 38: 481-98. https://doi.org/10.1007/s11217-019-09674-z.

Siemens, George. 2004. "Connectivism: A Learning Theory for a Digital Age." http://www.itdl.org/journal/jan_05/article01.htm.

Swan, Karen, Cheng-Chia Chen, and Denise Bockmier-Sommers. 2020. "Relationships between Carl Rogers' Person-Centered Education and the Community of Inquiry Framework: A Preliminary Exploration.” Online Learning 24. https://doi.org/10.24059/olj.v24i3.2279.

Victor, Stephen P., and Shannon Hart. 2016. "Distributed Learning: A Flexible Learning and Development Model." Paper presented at the E-Learn 2016 Conference,14-16 November, Washington, United States.

Vygotsky, Lev S. 1978. Mind in Society: The Development of Higher Psychological Processes. London: Harvard University Press.

Wenger, Etienne. 1998. Communities of Practice: Learning, Meaning, and Identity. Cambridge: Cambridge University Press.

Wenger, Etienne, Richard McDermott, and William M. Snyder. 2002. A Guide to Managing Knowledge: Cultivating Communities of Practice. Boston: Harvard Business School Press.

Wu, Jie. 2020. Distributed System Design. New York: Routledge.

Zawacki-Richter, Olaf, Diane Conrad, Aras Bozkurt, Cengiz Aydin, Svenja Bedenlier, Insung Jung, Joachim Stöter, George Veletsianos, Lisa Marie Blaschke et al. 2020. "Elements of Open Education: An Invitation to Future Research." International Review of Research in Open and Distributed Learning 21 (3): 319-34. https://doi.org/10.19173/irrodl.v21i3.4659. 
Zhao, Huahui, Kirk P. H. Sullivan, and Ingmarie Mellenius. 2014. "Participation, Interaction and Social Presence: An Exploratory Study of Collaboration in Online Peer Review Groups." British Journal of Educational Technology 45 (5): 807-19. https://doi.org/10.1111/bjet.12094. 